$\sqrt{B}$

J. Bio-Sci. 25: 39-44, 2017

ISSN 1023-8654

http://www.banglajol.info/index.php/JBS/index

\title{
PRESENT STATUS OF FISH AVAILABILITY IN RUHUL BEEL, NORTHERN BANGLADESH
}

\author{
SS Maya and MMR Mondol* \\ Department of Fisheries, Faculty of Agriculture, University of Rajshahi, Bangladesh
}

\begin{abstract}
This study was conducted in Ruhul Beel, Pabna, northern area of Bangladesh to know the availability of different fish species. Samples were collected fortnightly from the fishermen catch captured in different points of the Beel during January to December, 2013. During this study a total of 37 fish species under 9 orders and 19 families were recorded from the study area. Cypriniformes was the most dominant order constituting $32.43 \%$ of the total fish populations followed by the Siluriformes (27.02\%), Perciformes (21.62\%), Channiformes (5.4\%) and Clupeiformes (2.7\%). On the contrary, Beloniformes, Cyprinodontiformes, Osteoglossiformes and Tetraodontiformes were the least numerous orders constituting only $2.71 \%$ each of the total fish populations. Among the available fish species, $37.84 \%$ were very rare, $35.14 \%$ were rare, and $21.61 \%$ were found throughout the year in a small amount while only $5.41 \%$ were available throughout the year in a large amount. About half of the fish species available in the Ruhul Beel is threatened to extinct according to IUCN Bangladesh. The results of this study will provide important baseline data on availability of fish species, which will be helpful for the sustainable management and conservation of fisheries diversity in the Ruhul Beel as well as in the open waterbodies of Bangladesh.
\end{abstract}

Key words: Bangladesh, fish availability, Ruhul Beel, threatened fish

\section{Introduction}

Freshwater fishes are the most diverse group of vertebrates, constitutes a vital component of the world, with a species richness compared to both terrestrial and marine ecosystems (Gleick 1996, Duncan and Lockwood 2001). Freshwater biodiversity has declined faster than either terrestrial or marine biodiversity over the years (Jenkins 2003). The major conservation problems of freshwater fish is the fact that the freshwater fish occupy comparatively limited space with much reduced ability for inter-basin movement (UNESCO 2003, Stoddard et al. 2006) contrary to the fairly free moving marine fish (Andrew and Pepperell 1992). Freshwater biodiversity is in a state of critically endangered due to the climate change and habitat destruction (Stoddard et al. 2006). In Bangladesh, human activities and annual environmental effects e.g., dry season and flooding continue to cause considerable damage to the production of inland freshwater ecosystems as well as some fishing methods also been criticized as being environmentally damaging (Andrew and Pepperell 1992). The collection of fish fry during pre-monsoon season, heavy siltation during rainy seasons negatively impacts the inland open water fisheries production as well as growth and development of fish species (Mondol et al. 2015). In 2000, a study by IUCN revealed that 54 of the major inland fish species in Bangladesh are threatened at varying degree (IUCN 2000). Among the commonly cited causes for the deterioration of the fishery resources is the loss of fish habitat, largely caused by the construction of roads, embankments, drainage, flood control and occurrences of natural siltation, along with over fishing (Hughes et al. 1994, Ali

*Author for correspondence: mostafiz_bau@yahoo.com 
1997). Enactment of the existing legislations is required for initiating sustainable fisheries management program for conserving or developing the resources.

Knowledge of the existing resources and their condition are therefore essential for planning of any management program for conserving or developing the resources. Ruhul Beel, is an important freshwater fish habitat in northern Bangladesh. However, due to various anthropogenic and natural reasons water flow of this beel decreased significantly in recent years and results in threatening of the aquatic biodiversity. To the best of our knowledge, there is no previous scientific information on the availability of fish species in this beel. Therefore, this study was designed to investigate the fish species availability in the Ruhul Beel, Pabna, northern area of Bangladesh.

\section{Materials and Methods}

The present study was conducted in the Ruhul Beel $\left(24014^{\prime} \mathrm{N}\right.$ and $\left.89{ }^{\circ} 24^{\prime} \mathrm{E}\right)$ at Bhangura upazila under Pabna district of northern area of Bangladesh. The beel covers about 100 hectare in area and is one of the prime habitat for fresh water fishes in Bangladesh. Fish samples were collected fortnightly from the fishermen catch captured in different points of the beel during January to December, 2013. Fish were caught using Bhesal jal (Khara jal), Ber jal, Moi jal, cast net and monofilament fixed fill net. Collected fish samples were fixed in $10 \%$ formalin at the site and identification was done upon arrival at the laboratory based on their morphometric and meristic characteristics according to Talwar and Jhingran (1991) and Froese and Pauly (2011). Fish availability, threats to fish diversity and conservation needs were determined because of fish abundance during sampling, market survey, interviewing fishermen and fish cognate personnel using pre-structured questionnaire (Rahman et al. 2012 a,b). Fish availability was classified as TY (throughout the year), TYS (throughout the year in small amount), TYL (throughout the year in large amount), SM (found in small amount during monsoon), LM (found in large amount during monsoon), R (rare), VR (very rare) and NE (not evaluated) (Mondol et al. 2015).

\section{Results and Discussion}

The present study recorded a total of 37 fish species under 9 orders and 19 families from the Ruhul Beel (Table 1). Cypriniformes was the foremost order constituting $32.43 \%$ of the total fish population followed by the Siluriformes (27.02\%), Perciformes (21.62\%), Channiformes (5.40\%) and Clupeiformes (2.70\%). On the contrary, Beloniformes, Cyprinodontiformes, Osteoglossiformes and Tetraodontiformes were the least numerous orders constituting only $2.71 \%$ each of the total fish population (Fig. 1). The dominance of the orders Cypriniformes, Siluriformes and Perciformes in freshwater fish population is common in Indian subcontinent (IUCN Bangladesh 2000, Shinde et al. 2009, Emmanuel and Modupe 2010, Khan and Hasan 2011, Nyant et al. 2012, Mondol et al. 2015). Cyprinidae was the most dominant family constituting $24.32 \%$ of the total fish population.

Among the available fish species, $37.84 \%$ were very rare while $35.14 \%$ were rare, $21.61 \%$ were found throughout the year in a small amount while only $5.41 \%$ were available throughout the year in a large amount (Fig. 2). $8.1 \%$ of the available species were critically endangered, $13.51 \%$ were endangered and $16.21 \%$ were vulnerable, $8.1 \%$ were data deficient, $51.35 \%$ were not threatened, $2.70 \%$ were not listed according to IUCN Bangladesh (2000).

Still to date previous studies on fish availability in the Ruhul Beel are unavailable in the literature. Therefore, this documentation on species availability will compose the foundation for further comprehensive studies. However, it is imperative that many of the threatened to extinction fish species be still dwelling in the Ruhul Beel. Our preliminary survey showed that, abstraction of water for irrigation, use of agro-chemicals in 
surrounding crop fields besides the beel, over exploitation and indiscriminate use of gears are the main threat for fish species conservation in the Ruhul Beel. Besides, there is only one-way management policy is to make sanctuary in the deepest part of the beel, where fishing is completely banned. But this policy is not properly followed. The implementation of this sanctuary and some other beel management policy like, seed production, MACH (Management of aquatic resources through community husbandry), CBFM (Community based fisheries management), and integrated aquaculture technologies should be adopted to protect the species which are a degree of extinction and to recover sustainable production of the Ruhul Beel. For this purpose, the following immediate actions may be recommended such as prohibition on harvesting brood fish, stocking of fish fry and ban of fishing by illegal gears. Therefore, it is most urgent to take suitable step to protect fish fauna of Bangladeshi beel. In the light of the present study of Ruhul Beel, it is the time to make proper policies and necessary steps to implement so that the future generation can get the fishes lively on the earth rather than photographs in literature.

Table 1. Check-list of fish availability in the Ruhul Beel, northern Bangladesh.

\begin{tabular}{|c|c|c|c|c|c|}
\hline Order & Family & Scientific name & Local name & Availability & $\begin{array}{l}\text { Present } \\
\text { status }\end{array}$ \\
\hline Beloniformes & Belonidae & Xenentodon cancila & Kaikka, Kakila & TYS & NT \\
\hline \multirow[t]{2}{*}{ Channiformes } & \multirow[t]{2}{*}{ Channidae } & Channa striatus & Shol & $\mathrm{R}$ & NT \\
\hline & & Channa punctatus & Taki & TYL, LM & NT \\
\hline Clupeiformes & Engraulidae & Gudusia chapra & Chapila, Khoira & $\mathrm{R}$ & $\mathrm{DD}$ \\
\hline \multirow[t]{12}{*}{ Cypriniformes } & \multirow[t]{3}{*}{ Cobitidae } & Botia dario & Rani, Bau Mach & VR & EN \\
\hline & & Botia lohachata & Rani, Bau Mach & VR & EN \\
\hline & & Lepidocephalus guntea & Puiya, Gutum & $\mathrm{R}$ & NT \\
\hline & \multirow[t]{9}{*}{ Cyprinidae } & Ablypharyngodon mola & Mola, Moa & TYS & NT \\
\hline & & Esomus danricus & Darkina & TYS & $\mathrm{DD}$ \\
\hline & & $\begin{array}{l}\text { Hypophthalmichthys } \\
\text { molitrix }\end{array}$ & Silver carp & $\mathrm{R}$ & NT \\
\hline & & Labeo calbasu & Kalibaus & $\mathrm{R}$ & EN \\
\hline & & Labeo rohita & Rui, Rohit & $\mathrm{R}$ & NT \\
\hline & & Systomus sarana & Sar-punti & VR & $\mathrm{CR}$ \\
\hline & & Puntius sophore & Jat punti, punti & TYS & NT \\
\hline & & Pethia ticto & Tit-punti & TYS & VU \\
\hline & & Salmostoma phulo & Chela & VR & NT \\
\hline Cyprinodontiformes & Cyprinodontidae & Aplocheilus panchax & Panchax & $\mathrm{R}$ & NT \\
\hline Osteoglossiformes & Notopteridae & Notopterus notopterus & Foli, Kanla & VR & VU \\
\hline
\end{tabular}


Table 1 Contd.

\begin{tabular}{|c|c|c|c|c|c|}
\hline \multirow[t]{8}{*}{ Perciformes } & Anabantidae & Anabas testudineus & Koi & $\mathrm{R}, \mathrm{SM}$ & $\mathrm{DD}$ \\
\hline & Osphronemidae & Colisa fasciatus & Kholsha & TYL, LM & NT \\
\hline & Ambassidae & Chanda nama & Chanda & TYS, SM & VU \\
\hline & Gobiidae & Glossogobius giuris & Baila, Bele & $\mathrm{R}$ & NT \\
\hline & Mastacembelidae & Macrognathus aculetus & Tara baim & $\mathrm{R}$ & VU \\
\hline & & Mastacembelus armatus & Tara baim & $\mathrm{R}$ & EN \\
\hline & & Mastacembelus puncalus & Guchi & TYS & NT \\
\hline & Nandidae & Nandus nandus & Bheda, Meni & VR & VU \\
\hline \multirow[t]{10}{*}{ Siluriformes } & Bagridae & Mystus cavassius & Kabshi tengra & VR & VU \\
\hline & & Mystus tengara & Tengra & $\mathrm{R}$ & NT \\
\hline & & Mystus vittatus & Taila air & $\mathrm{R}$ & NT \\
\hline & Heteropneustidae & Heteropneustes fossilis & Shing & TYS & NT \\
\hline & Schilbeidae & Clupisoma garua & Ghere, Gharua & VR & $\mathrm{CR}$ \\
\hline & & Eutropiichthys vacha & Vacha & VR & CR \\
\hline & & $\begin{array}{l}\text { Pseudeutropius } \\
\text { atherinoides }\end{array}$ & Batasi & VR & NT \\
\hline & Siluridae & Ompok bimaculatus & Kani pabda & VR & EN \\
\hline & & Wallago attu & Boal & VR & NT \\
\hline & Sisoridae & Gagata gagata & Gun tengra & VR & NT \\
\hline Tetraodontiformes & Tetraodontidae & Tetraodon cutcutia & Potka & VR & NT \\
\hline
\end{tabular}

TYS, throughout the year in small amount; TYL, throughout the year in large amount; SM, found in small amount during monsoon; LM, found in large amount during monsoon; R, rare; VR, very rare; Status in the IUCN Red List according to IUCN Bangladesh (2000), EN-Endangered, VU- Vulnerable, CR- Critically endangered DD-Data deficient, NT- Not threatened, NL- Not listed. 


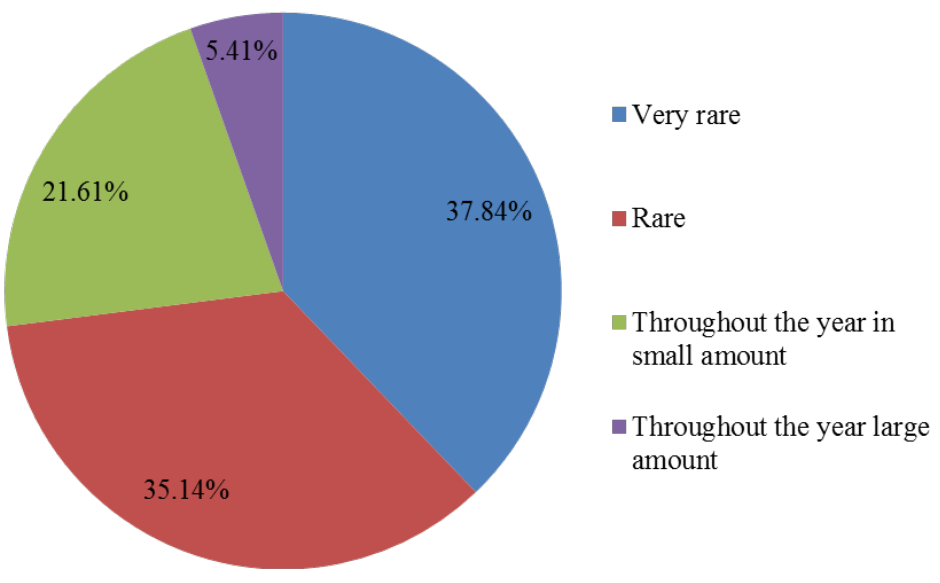

Fig. 1. Fish species availability (percentage) in Ruhul Beel during the study period.

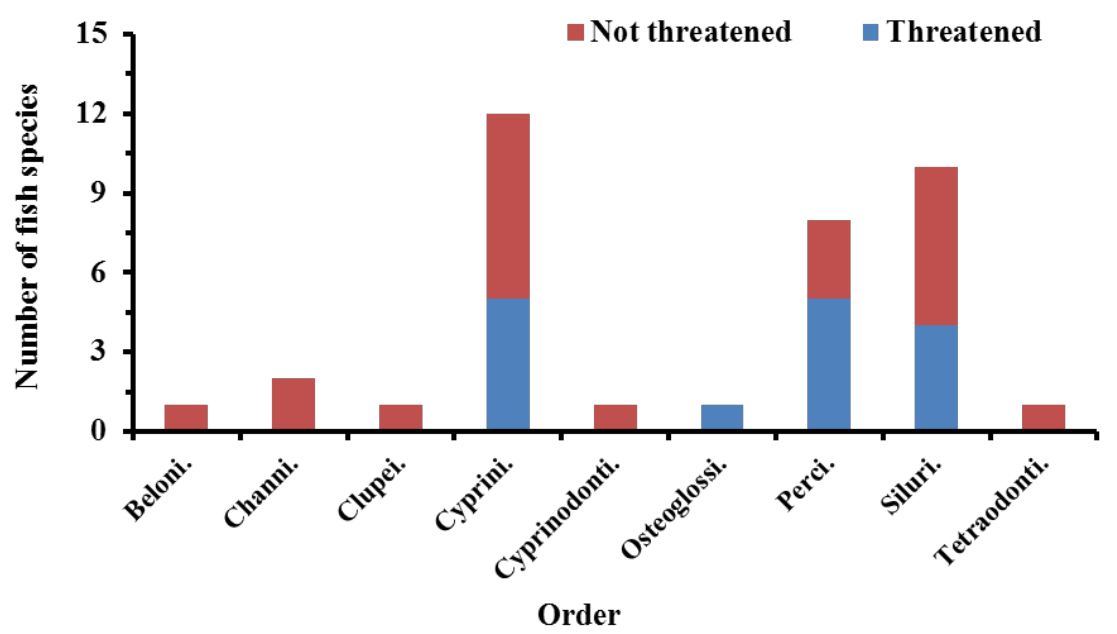

Fig. 2. Number of threatened to extinction and non-threatened fish species under different order in Ruhul Beel during the study period.

\section{Acknowledgement}

The authors express their gratitude to the Department of Fisheries, Faculty of Agriculture, University of Rajshahi, Bangladesh for laboratory facilities and Md. Mahbubur Rahman, Upazila Fisheries Officer Bhangura, Pabna for his help during collection of the fish specimens. 


\section{References}

Ali MY (1997). Fish, water and people reflections on inland open water fisheries resources of Bangladesh, the university press limited, Dhaka, Bangladesh.

Andrew NL and Pepperell JG (1992). The bycatch of shrimp trawl fisheries. Ocenography and Marine Biology: An Annual Review 30: 527-565.

Duncan JR and Lockwood JL (2001). Extinction in a field of bullets: a search for causes in the decline of the world's freshwater fishes, Biodiversity and Conservation 102: 97-5.

Emmanuel LO and Modupe OO (2010). Fish diversity in three tributaries of River Ore, South West Nigeria, World Journal of Fish and Marine Sciences 2(6): 524-531.

Froese R and Pauly D (Eds.) (2011). Fish Base: World Wide Web electronic publication. URL:www.fishbase.org http//:www.fishbase.org [version 08/2011].

Gleick PH (1996). Water resources. In Encyclopedia of Climate and Weather, ed. by Schneider SH, Oxford University Press, New York, vol. 2, 817-823 pp.

Hughes R, Adnan S and Dalal-Clayto, B (1994). Floodplains or Flood Plans: A review of approaches to water management in Bangladesh. International Institute for Environment and Development, London; and Research and Advisory Services, Dhaka, Bangladesh.

IUCN, Bangladesh (2000). Red Book of Threatened Fishes of Bangladesh. Ameen M, Islam A, Nishat A, (eds). The World Conservation Union, Dhaka, Bangladesh, xi: 116 pp.

Jenkins M (2003). Prospects for biodiversity, Science 302: 1175-1177.

Khan MA and Hasan Z (2011). A preliminary survey of fish fauna of Changhoz dam, Karak, K.P.K. Pakistan, World Journal of Fish and Marine Sciences 3(5): 376-378.

Mondol MMR, Hossain MY and Rahman MM (2015). Check-List of Fish Availability in the Karatoya River, Bangladesh, World Journal of Zoology 10(1): 17-21.

UNESCO (2003). The United Nations World Water Development Report: Water for People, Water for Life. The United Nations Educational, Scientific and Cultural Organization (UNESCO), and Berghahn Books, 595 pp.

Nyanti L, Ling TY and Jongkar G (2012). Fish crustacean communities and fish length weight relationship of Lutong River, Miri, Sarawak, Malaysia, World Journal of Fish and Marine Sciences 4(1): 102-110.

Rahman MM, Hossain MY, Ahamed F, Fatematuzzhura, Subba BR, Abdallah EM and Ohtomi J (2012a). Biodiversity in the Padma distributary of the Ganges River, northwestern Bangladesh: Recommendations for conservation, World Journal of Zoology 7(4): 328-337.

Rahman, MM, Hossain MA, Fatematuzzhura, Tasnoova S, Ahamed F, Hossain MY, Subba BR and Ohtomi J (2012b). Fresh fish marketing status in the northwestern Bangladesh: Recommendations for Sustainable Management, Nature 10: 128-136.

Shinde SE, Pathan TS, Raut KS, Bhandare RY and Sonawane DI (2009). Fish Biodiversity of Pravara river at Pravara Sangam District Ahmednagar, India, World Journal of Zoology 4(3): 176-179.

Stoddard JL, Larsen DP, Hakins CP, Johnson RK and Norris RH (2006). Setting expectations for the ecological conditions of streams: The concept of reference condition. Reference conditions-Ecological applications (available on internet at http://watersheds.motana.edu).

Talwar PK and Jhingran AG (1991). Inland fishes of India and adjacent countries. Balkema AA, Rotterdam, 1: 541 pp. 